\title{
Preliminary analysis of hybrid laparoscopic procedure for resection of gastric submucosal tumors
}

\section{Avaliação preliminar do procedimento videolaparoscópico híbrido para ressecção de tumores gástricos submucosos}

Pedro Henrique lambach Caron'; Mariana Ismael Dias Martins'; Pedro luiz Bertevello'.

\begin{abstract}
A B S T R A C T
Objective: to evaluate the feasibility, safety and benefits of minimally invasive surgery for resection of gastric submucosal tumor (GSMT). Methods: we conducted a retrospective study of medical records of patients undergoing endoscopy-assisted laparoscopic resection of gastric submucosal tumors (prospectively collected) from 2011 to 2014. We evaluated clinical data, surgical approach, clinicopathological characteristics of the GSMT (size, location, histopathological and immunohistochemical exams), outcome and patients follow-up. Results: we evaluated six patients, $50 \%$ male, mean age $52 \pm 18$ years and common symptoms of heartburn and gastric fullness. All patients underwent hybrid procedure without anatomical impairment of the organ. The average length of stay was 3.5 days and the average size of the tumors was $2.0 \pm 0.8 \mathrm{~cm}$, five of them (83\%) in the proximal third of the stomach. The surgical specimens pathological and immunohistochemistry examination revealed one case of ectopic pancreas (17\%), one grade 2 neuroendocrine tumor (17\%), one lipoma (17\%), one GIST (17\%) and two leiomyomas (32\%). There were no episodes of tumor rupture or intraoperative complications and no conversion to open surgery. During the postoperative follow-up period, none of the patients had recurrence, metastasis, fistula or stenosis. Conclusion: the results showed that endoscopy-assisted laparoscopic resection is feasible and safe for patients with GSMT. Endoscopy proved to be essential in the location of lesions and as intraoperative support, especially when attempting to preserve the pylorus and cardia during surgery.
\end{abstract}

Keywords: Surgical Procedures, Operative. Video-Assisted Surgery. Leimyoma.

\section{INTRODUCTION}

G astric subepithelial lesions are common findings during routine upper endoscopy, usually identified as a mass, lump or imprint covered by normal mucosa. The actual incidence of these lesions is difficult to estimate, being found in up to $0.4 \%$ of the population ${ }^{1,2}$. Macroscopically, they exhibit a broad spectrum; they can be benign or malignant, the gastrointestinal stromal tumors (GISTs) being the most common type. Currently, is indicated for diagnosis of submucosal gastric tumors ${ }^{1,2}$.

Local excision with adequate surgical margins is indicated in most cases of gastric submucosal tumors (GSMT)2. Depending on their characteristics, they can be resected endoscopically, laparoscopical$l^{3}$, or through a hybrid procedure. The laparoscopic resection technique was first applied by Ohgami et al., in $1999^{4}$. However, the use of the laparoscopic method can show methodological limitations for resection, for example, the size of the lesion ${ }^{1-3}$. Intraoperative upper endoscopy helps locating the tumor and evaluates safely surgical resection. Thus, laparoscopic resection assisted by endoscopy is indicated for the removal of GSMT (leiomyomas, lipomas and schwannomas), broad-base polyps, gastric epithelial tumoral degeneration (moderate or severe atypical hyperplasia), ectopic pancreas, low malignant potential lesions (carcinoid tumor and GIST), and some cases of early gastric carcinoma ${ }^{3,5}$.

Given the above and the limited literature, the aim of this study was to evaluate the feasibility, safety and advantages of applying the hybrid method for resection of gastric submucosal tumors in a specialized service.

\section{METHODS}

We conducted a descriptive study, in which we analyzed the hospital records of six patients un-

1. Hospital Beneficência Portuguesa de São Paulo - Pro Gastro, São Paulo, SP, Brasil. 
dergoing endoscopy-assisted laparoscopic resection for gastric submucosal tumors, from March 2011 to May 2014, by the Gastrosurgery team (ProGastro) in the Real e Benemérita Associação Portuguesa de Beneficência de São Paulo.

All patients underwent upper endoscopy with biopsy, total abdominal ultrasound and/or CT scan, laboratory tests (including tumor markers) and endoscopic ultrasonography in selected cases.

We analyzed demographic and preoperative clinical characteristics (gender, age and duration of the operative procedure), and postoperative data included possible surgical complications and length of stay. The clinicopathological characteristics of resected GSMT included size, location, histopathology and immunohistochemistry (Table 1).

Regarding the surgical procedure, patients were placed in the supine position under general anesthesia, according to the American Technique (AT ${ }^{6}$, with the surgeon positioned to the right of the patient. Video monitors were placed laterally to the patient's shoulders. The abdominal cavity is accessed with a Veress needle for establishing the pneumoperitoneum and passage of the optics trocar $(10 \mathrm{~mm})$ in the midline, about 10 to $12 \mathrm{~cm}$ from the xiphoid process. We inserted four additional trocars (three $5 \mathrm{~mm}$ and one $12 \mathrm{~mm}$ in diameter) as diagrammed in Figure 1 under direct vision of a rigid $30^{\circ}$ laparoscope.

Intraoperative upper endoscopy was performed to define the location of the lesion, determine the most appropriate technique for resection, evaluate the resection margins and the integrity of the suture lines after resection. The injuries were not directly manipulated with laparoscopic instruments to prevent tumor rupture.

Once the patient is anesthetized, the endoscope is introduced through the oropharynx. The lining of the esophagus and stomach was evaluated with care not to overly inflate the stomach. The location of the GSMT was confirmed, all liquids and gas taken from the gastric chamber and the endoscope retracted through the cardia, staying in the esophagus.

Tumors in the anterior gastric wall were resected after endoscopic location of the cardinal points of the lesion to define the resection safety

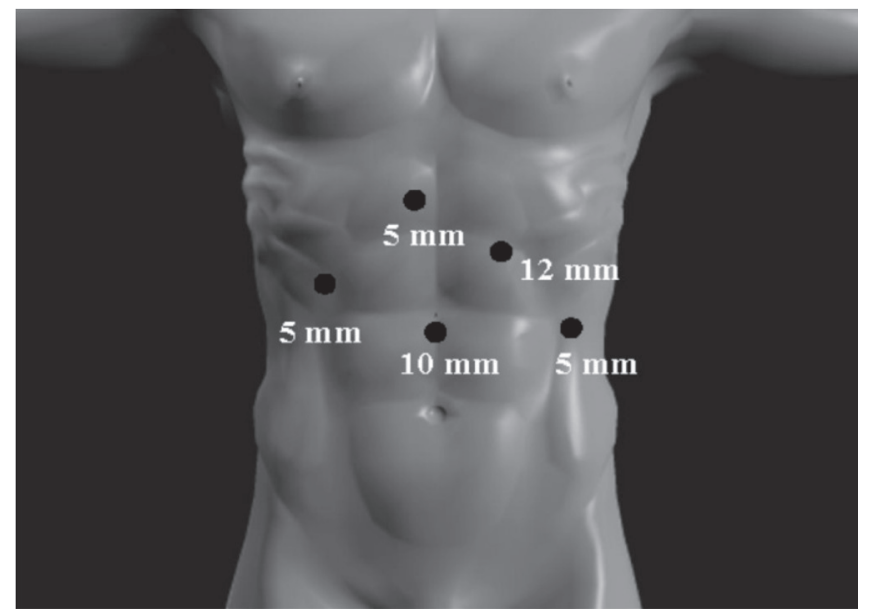

Figure 1. Insertion of the trocars for realization of the laparoscopic resection of gastric submucosal tumors after instilation of the pneumoperitoneum.

margin. Tumors were resected with ultrasonic coagulation shears. The gastrotomy was closed in two planes of continuous, multifilament, absorbable suture, followed by a novel endoscopic evaluation to ensure complete resection of the lesion, to perform a hyperinflation maneuver to rule extravasation and to review hemostasis of the suture line. The resected specimens were packed in an endoscopic recovery bag and removed from the abdominal cavity. Tumors of the posterior gastric wall were resected after the release of the gastric curvature that was nearest to the tumor for proper exposure, using the ultrasonic coagulating shears. Then the posterior wall was exposed, and the tumor, removed through a technique similar to that described for the previous lesions.

We used the transgastric technique in one case, with gastrotomy of the anterior wall and resection of the posterior wall lesion with electrocautery and ultrasonic coagulating shears. We then closed the anterior wall gastrotomy with absorbable, multifilament suture, in a continuous fashion.

One of the patients who had a tumor in the gastric greater curvature, after release of the greater omentum, had his lesion resected with laparoscopic stapler.

On the first day after surgery we instituted a fractionated liquid diet with progression till acceptance of regular diet, when the patient was discharged. Routine outpatient visits were set to 10 and 30 days postoperatively. Upper endoscopy was per- 
formed about six months and one year after surgery, and repeated annually for two years. Follow up with imaging tests such as computed tomography of the chest or abdomen, magnetic resonance imaging of the chest or abdomen and pet Scan $®$ were indicated should we find any abnormality. The follow-up ranged from six months to one year.

Descriptive statistics were performed and the study was approved by the Ethics in Research Committee of the Hospital Beneficência Portuguesa de São Paulo, opinion 1035/2014, with informed consent of the participants.

Table 1. Preoperative clinicopathological characteristics of gastric submucosal tumors submitted to upper digestive endoscopy and/or endoscopic ultrasound with fine needle aspiration (FNA) biopsy.

\begin{tabular}{|c|c|c|c|c|}
\hline $\begin{array}{l}\text { Gender/age } \\
\text { (years) }\end{array}$ & $\begin{array}{l}\text { PREOPERATIVE } \\
\text { ENDOSCOPY }\end{array}$ & $\begin{array}{l}\text { LESION } \\
\text { LOCATION }\end{array}$ & $\begin{array}{l}\text { ENDOSCOPIC } \\
\text { ULTRASOUND }\end{array}$ & BIOPSY \\
\hline Female/61 & $\begin{array}{c}\text { Subepithelial } \\
\text { tumor with stromal } \\
\text { appearance }\end{array}$ & Gastric Fundus & No & No \\
\hline Female/31 & $\begin{array}{l}\text { Gastritis, subepithelial } \\
\text { lesion, } 2 \mathrm{~cm}\end{array}$ & Subcardia & $\begin{array}{c}\text { Mobile lesion on } \\
\text { Cardia muscular } \\
\text { layer (Leiomyoma? } \\
\text { GIST?). Hypoechoic } \\
\text { lesion, regular and } \\
\text { heterogeneous, } 1, .7 \times 1.5 \\
\mathrm{~cm} .\end{array}$ & $\begin{array}{c}\text { Leiomyoma } \\
\text { (mesenchymal } \\
\text { neoplasia). Mitotic } \\
\text { activity not detected } \\
\text { necrosis not detected, } \\
\text { mild pleomorphism }\end{array}$ \\
\hline Male/50 & $\begin{array}{l}\text { Elevated, lobulated } \\
\text { lesion, covered } \\
\text { with intact mucosa, } \\
\text { measuring } 3 \mathrm{~cm} \text {, which } \\
\text { protrudes from the } \\
\text { cardia to the small } \\
\text { curvature (GIST?). }\end{array}$ & Cardia & $\begin{array}{l}\text { Subepithelial lesion } \\
\text { on muscular layer, } \\
\text { compatible with } \\
\text { leiomyoma }\end{array}$ & $\begin{array}{l}\text { Mesenchymal } \\
\text { neoplasm of low } \\
\text { degree (Leiomyoma). } \\
\text { Irregular structures: } \\
3.5 \times 2.7 \times 1 \mathrm{~cm} \text { and } \\
5.3 \times 0.3 \times 3 \mathrm{~cm}\end{array}$ \\
\hline Female/85 & $\begin{array}{l}\text { Elevated lesion in } \\
\text { greater curvatuve, of } \pm \\
2 \mathrm{~cm}\end{array}$ & Greater curvature & No & No \\
\hline Male/31 & $\begin{array}{l}\text { Elevated lesion of } \\
\text { gastric body of } 1.3 \mathrm{~cm} \text {, } \\
\text { proximal body in lesser } \\
\text { curvature, no biopsy }\end{array}$ & $\begin{array}{l}\text { Posterior gastric } \\
\text { wall }\end{array}$ & $\begin{array}{l}\text { Posterior gastric wall } \\
\text { lesion of } 5 \mathrm{~cm} \text { far from } \\
\text { the GET *, smooth } \\
\text { surface, hiperemy, } \\
\text { with discreet apical } \\
\text { depression, firm, with } \\
\text { irregular submucose } \\
\text { vessels of } 1.3 \mathrm{~cm} \text {. }\end{array}$ & $\begin{array}{l}\text { Biopsy of the lesion in } \\
\text { GET, histological grade } \\
2 \text { neuroendocrine } \\
\text { neoplasia/tumor in } \\
\text { cardia pattern mucosa }\end{array}$ \\
\hline Male/58 & $\begin{array}{l}\text { smooth subepithelial } \\
\text { lesion of about } 12 \mathrm{~mm} \\
\text { on the posterior face } \\
\text { of the medial antrum. } \\
\text { Acanthosis glycogen of } \\
\text { the esophagus. }\end{array}$ & Gastric antrum & $\begin{array}{c}\text { Submucosal lesion 1, } 3 \\
\mathrm{~cm}\end{array}$ & No \\
\hline
\end{tabular}

GET*: Gastro-esophageal transition. 


\section{RESULTS}

We analyzed the data of the six patients who underwent endoscopy-assisted laparoscopic resection of gastric submucosal tumors from March 2011 to May 2014. Of these patients, three were male and three female. The mean age was $52 \pm 18$ years (range $31-85)$. The most common symptoms among patients were heartburn and gastric fullness. All patients underwent preoperative upper endoscopy with macroscopic biopsy. Among these, four patients underwent endoscopic ultrasound with fine needle aspiration biopsy (Table 1).

The mean duration of surgery was $181 \pm 41$ minutes (range 145-250). In addition to the laparoscopic wedge resection, one patient also underwent laparoscopic inguinal hernia repair right, this procedure lasting longer (250 minutes).
The average length of stay was 3.5 days, ranging from three to four.

The average tumor size was $2.0 \pm 0.8 \mathrm{~cm}$ (varying from 1.0 to 3.4 ) and five of them (83.33\%) were located in the proximal third of the stomach. The location of the tumors was as follows: two in the cardia, two in the fundus, one in the body and one in the antrum. The cardia tumors were located in the gastric anterior wall, one being near the small gastric curve. Of the gastric fundus lesions, one was located in the greater curvature. The high gastric body tumor was located in the posterior wall and near the gastric lesser curvature. The antral tumor was located in the posterior wall.

The preoperative histopathologic study obtained the following results: one endoscopic lesion suggestive of GIST $(1.7 \times 1.5 \mathrm{~cm})$ and FNA suggesting leiomyoma; one $3.5 \times 2.7 \mathrm{~cm}$ lesion suggestive

Tabela 2. Características clínico-patológicas dos tumores submucosos gástricos ressecados (tamanho, localização, exame anatomopatológico e imuno-histoquímico)

\begin{tabular}{|c|c|c|c|c|}
\hline Paciente & Tamanho & Localização & Anatomopatológico & Imuno-histoquímica \\
\hline Female, 61 years & $1,0 \mathrm{~cm}$ & Gastric Fundus & $\begin{array}{c}\text { Ectopic Pancreas } \\
\text { Absence of neoplasia }\end{array}$ & \\
\hline Female, 31 years & $1,5 \mathrm{~cm}$ & $\begin{array}{l}\text { Cardia/ anterior } \\
\text { wall }\end{array}$ & $\begin{array}{l}\text { Leiomyoma, } \\
\text { absence of tumor } \\
\text { necrosis, cellular } \\
\text { atypia or mitosis }\end{array}$ & $\begin{array}{c}\text { Leiomyoma, } \\
\text { Vimentin +/ Actin+/ } \\
\text { Desmin+/Ki } 67+\text { in less } \\
\text { than } 1 \% / \mathrm{HHF}-35+\end{array}$ \\
\hline Male, 50 years & $3,0 \mathrm{~cm}$ & $\begin{array}{l}\text { Cardia/anterior } \\
\text { wall/ lesser } \\
\text { curvature }\end{array}$ & $\begin{array}{l}\text { Leiomyoma, } \\
\text { absence of tumor } \\
\text { necrosis, cellular } \\
\text { atypia or mitosis }\end{array}$ & $\begin{array}{c}\text { Leiomyoma, } \\
\text { Actin diffusely +/ difuse } \\
\text { Desmin / Ki } 67+\text { in less } \\
\text { than } 1 \%\end{array}$ \\
\hline Female, 85 years & $3,4 \mathrm{~cm}$ & $\begin{array}{l}\text { Gastric fundus/ } \\
\text { greater curvature }\end{array}$ & $\begin{array}{c}\text { Stromal tumor (GIST), } \\
\text { necrosis (3\%), } \\
\text { Mitotic activity: 04/10 } \\
\text { CGA }\end{array}$ & $\begin{array}{c}\text { GIST } \\
\text { CD-117+/ c-kit + / CD- } \\
34+\end{array}$ \\
\hline Male, 31 years & $1,3 \mathrm{~cm}$ & $\begin{array}{l}\text { High body/ } \\
\text { posterior wall/ } \\
\text { lesser curvature }\end{array}$ & $\begin{array}{c}\text { Grade } 2 \\
\text { neuroendocrine } \\
\text { tumor (NET G2) } \\
\text { Mitotic activity: 01/10 } \\
\text { CGA }\end{array}$ & $\begin{array}{c}\text { NETG2, } \\
\text { CK 8/CK 18 +/ } \\
\text { chromogranin +/ } \\
\text { synaptophysin+/ CD } \\
56+/ \text { Ki } 67+(3-5 \% \\
\text { of neoplastic cells)/ } \\
\text { somatostatin -/ glucagon } \\
\text {-/ serotonin -/ insulin -/ } \\
\text { gastrin - } \\
\end{array}$ \\
\hline Male, 58 years & $2,0 \mathrm{~cm}$ & $\begin{array}{c}\text { Antrum/posterior } \\
\text { wall }\end{array}$ & Lipoma & \\
\hline
\end{tabular}


of leiomyoma; one case of a $1.3 \mathrm{~cm}$ lesion with FNA suspecting neuroendocrine tumor; one $1.2 \mathrm{~cm}$ lesion with inconclusive FNA. In two cases ewe have not performed FNA: in one of these, the endoscopic appearance was of a $1.2 \mathrm{~cm}$ stromal tumor; and in the other, with a $2 \mathrm{~cm}$ gastric fundus lesion, there were technical problems preventing biopsy by eco-endoscopy.

In the post-resection pathology study, we obtained the following results: one ectopic pancreas, two leiomyomas, one GIST, one grade 2 neuroendocrine tumor and one lipoma. The latter was operated on due to the preoperative endoscopic suspicion of GIST. One leiomyoma presented the following immunohistochemical analysis: vimentin (+); Actin (+); Desmin (+); Ki-67 (+) in less than 1\% and HHF-35 $(+)$. The other leiomyoma resulted in: Actin diffusely (+); Desmin diffuse and Ki-67 (+) less than 1\%. The GIST immunohistochemical analysis demonstrated: CD-117 (+); c-kit (+) and CD-34 (+). The grade 2 neuroendocrine tumor (NET G2) showed: CK 8 / CK $18(+)$; chromogranin A (+); synaptophysin (+); CD 56 $(+)$; Ki-67 (+) (3-5\% of neoplastic cells); Somatostatin $(-)$; glucagon (-); Serotonin (-); insulin (-), and gastrin (-) (Table 2).

There were no episodes of tumor rupture, intraoperative complications and no conversion to open surgery. None of patients showed immediate or late postoperative complications.

\section{DISCUSSION}

The laparoscopic and endoscopic surgical techniques have evolved and generated good results in the treatment of benign and malignant gastrointestinal diseases. To date, only case reports have been published on the application of a laparoendoscopic approach GSMT resection ${ }^{7}$. Hence, the relevance of this study.

GSMT are rare lesions that are being more frequently diagnosed because of the ease and awareness of the importance of routine endoscopic examination. They are usually observed as a mass, lump, or imprint covered by normal mucosa. The actual incidence rate of these lesions is difficult to estimate and can be found in up to $0.4 \%$ of the population ${ }^{1,8,9}$.

With respect to the location, in $83.3 \%$ of GSMT were in the proximal stomach, corroborating the literature, which states that two-thirds of these tumors are located in this region ${ }^{10}$. In $59.1 \%$ of patients, the tumors were located at the fundus and the resection next to the cardia could result in symptoms of gastroesophageal reflux $x^{9,11,12}$.

Another point of discussion taken into consideration is that tumors located in the middle third of the stomach can easily be treated by laparoscopy, while tumors in the proximal and distal thirds of the stomach, near the cardia and pylorus, are at increased risk of post-resection stenosis. Thus, some authors recommend open surgery for such locations. Recently, to prevent deformity or stenosis of these areas, several minimally invasive techniques with organ preservation are being developed ${ }^{1,7,11,13}$.

As for length of stay, the study of De Vogelaere et al. ${ }^{14}$ reported seven days for the laparoscopy group was compared with 14 days for the open group 4 . In our study, the length of stay was on average 3.5 days, below the average of studies found $d^{7,14,15}$. Other works also demonstrate lower incidence of post-operative pain, smaller wound size, early return of bowel function with return to normal diet and shorter postoperative hospital stay $^{15,16}$.

In our series, the approach to a stromal tumor (GIST) followed the main strategy to achieve an anatomical or non-anatomic resection, with tumor-free margins. This unique feature has allowed for a wider role of minimally invasive techniques, especially laparoscopic wedge gastrectomy, and was consistent with other studies regarding GIST treatment $2,4,8-11,14,17$. Concerning our patients' age, several studies describe that most patients with gastric GIST are in their sixth or seventh decade of life, with only $10 \%$ of patients are under $40^{12,14,15}$. According to the classification published by Fletcher et al. ${ }^{18}$, the GIST from this study was considered as low risk and did not require adjuvant therapy. The guidelines of the National Comprehensive Cancer Network ${ }^{19}$ before 2007 did not recommend 
laparoscopic surgery for GIST resection, except for tumors smaller than $2 \mathrm{~cm}$ in diameter and with a low rupture risk ${ }^{9}$. Although the tumor evaluated in this study was greater than $2 \mathrm{~cm}$ in diameter, we opted for the laparoscopic resection and confirmed the non-infringement of the capsule, which allows us to strengthen the laparoscopic indication regardless of tumor size. This result indicates that the performance of laparoscopic and endoscopic techniques by qualified operators, without contact with the tumor during surgery and the use of a sample recovery bags, is essential for good surgical results. Thus, as in the study Novitsky et al. ${ }^{20}$, we preserved the surgical margin of 1 to $2 \mathrm{~cm}$. Our results converge with the ones of these authors, who demonstrated to offer curative approach for all GIST, even if they are at higher risk and with a diameter greater than $5 \mathrm{~cm}$.

In conclusion, this study demonstrated the viability and satisfactory surgical outcomes of endoscopy-assisted laparoscopic resection of gastric benign lesions and GIST. Endoscopy was important to locate the tumor and evaluate the resection. The hybrid proposed technique proved therefore to be an alternative procedure for gastric wedge resection, with minimal gastric deformity.

\title{
R E S U M O
}

\begin{abstract}
Objetivo: avaliar a viabilidade, segurança e vantagens da cirurgia minimamente invasiva para ressecção de tumores submucosos gástricos (TUSG). Métodos: estudo retrospectivo dos prontuários de pacientes submetidos à ressecção videolaparoscópica assistida por endoscopia digestiva alta para tumores submucosos gástricos (coletados prospectivamente) de 2011 a 2014. Os fatores avaliados foram dados clínicos, abordagem cirúrgica, características clinicopatológicas dos TUSG (tamanho, localização, exame anatomopatológico e imuno-histoquímico), resultados e acompanhamento dos pacientes. Resultados: foram avaliados seis pacientes, 50\% do sexo masculino, com média de idade $52 \pm 18$ anos e sintomas comuns de pirose e plenitude gástrica. Todos os pacientes foram submetidos ao procedimento hibrido e sem comprometimento anatômico do órgão. O tempo médio de internação foi 3,5 dias e o tamanho médio dos tumores foi 2,0 $0,8 \mathrm{~cm}$, cinco deles (83\%) no terço proximal do estômago. Os exames anatomopatológicos e imuno-histoquímicos das peças cirúrgicas demonstraram um caso de pâncreas ectópico (17\%), um tumor neuroendócrino grau 2 (17\%), um lipoma (17\%), um GIST (17\%) e dois leiomiomas (32\%). Não houve episódios de ruptura do tumor nem complicações intraoperatórias e nenhuma conversão para cirurgia aberta. Durante o período de acompanhamento pós-operatório nenhum dos pacientes apresentou recidiva, metástase, fístula ou estenose. Conclusão: os resultados obtidos mostraram que a ressecção laparoscópica assistida por endoscopia é viável e segura para pacientes com TUSG. A endoscopia mostrou-se fundamental na localização das lesões e suporte intraoperatório, principalmente na tentativa de preservar a cárdia e o piloro durante a cirurgia.
\end{abstract}

Descritores: Procedimentos Cirurgicos Operatórios. Cirurgia Videoassistida. Leiomioma.

\section{REFERENCES}

1. Jeong $\mathrm{IH}$, Kim JH, Lee SR, Kim JH, Hwang JC, Shin SJ, et al. Minimally invasive treatment of gastric gastrointestinal stromal tumors: laparoscopic and endoscopic approach. Surg Laparosc Endosc Percutan Tech. 2012;22(3):244-50.

2. Sexton JA, Pierce RA, Halpin VJ, Eagon JC, Hawkins WG, Linehan DC, et al. Laparoscopic gastric resection for gastrointestinal stromal tumors. Surg Endosc. 2008;22(12):2583-7.

3. Wilhelm D, von Delius S, Burian M, Schneider A, Frimberger $E$, Meining $A$, et al. Simultaneous use of laparoscopy and endoscopy for minimally invasive resection of gastric subepithelial masses - analysis of 93 interventions. World J Surg. 2008;32(6):1021-8.

4. Linhares E, Gonçalves R, Valadão M, Vilhena B, Herchenhorn D, Romano S, et al. Gastrointestinal stromal tumor: analysis of 146 cases of the center of reference of National Cancer Institute - INCA. Rev Col Bras Cir. 2011;38(6):398-406.

5. Catena F, Di Battista M, Fusaroli P, Ansaloni L, Di Scioscio V, Santini D, et al. Laparoscopic treatment of gastric GIST: report of 21 cases and literature's review. J Gastrointest Surg. 2008;12(3):561-8.

6. Creuz O, Sorbello AA, Buzaid Neto A. Colecistectomia vídeo-laparoscópica: técnica cirúrgica. 
In: Creuz O, editor. Manual de cirurgia vídeo-endoscópica. Rio de Janeiro: Revinter; 1993. p. 135-50.

7. Barajas-Gamboa JS, Acosta G, Savides TJ, Sicklick JK, Fehmi SM, Coker AM, et al. Laparo-endoscopic transgastric resection of gastric submucosal tumors. Surg Endosc. 2015;29(8):2149-57.

8. Vecchio R, Marchese S, Amore FF, La Corte F, Ferla F, Spataro L, et al. Laparoscopic-endoscopic rendez-vous resection of iuxta-cardial gastric GIST. G Chir. 2013;34(5-6):145-8.

9. Tsujimoto $H$, Yaguchi $Y$, Kumano I, Takahata R, Ono S, Hase K. Successful gastric submucosal tumor resection using laparoscopic and endoscopic cooperative surgery. World J Surg. 2012;36(2):327-30.

10. Hiki N, Yamamoto $Y$, Fukunaga $T$, Yamaguchi $T$, Nunobe S, Tokunaga M, et al. Laparoscopic and endoscopic cooperative surgery for gastrointestinal stromal tumor dissection. Surg Endosc. 2008;22(7):1729-35.

11. Kang WM, Yu JC, Ma ZQ, Zhao ZR, Meng QB, Ye X. Laparoscopic-endoscopic cooperative surgery for gastric submucosal tumors. World J Gastroenterol. 2013;19(34): 5720-6.

12. Kim KH, Kim MC, Jung GJ, Kim SJ, Jang JS, Kwon $\mathrm{HC}$. Long term survival results for gastric GIST: is laparoscopic surgery for large gastric GIST feasible? World J Surg Oncol. 2012;10:230.

13. Dong HY, Wang YL, Li J, Pang QP, Li GD, Jia XY. New-style laparoscopic and endoscopic cooperative surgery for gastric stromal tumors. World J Gastroenterol. 2013;19(16):2550-4.

14. De Vogelaere K, Hoorens A, Haentjens P, Delvaux $G$. Laparoscopic versus open resection of gastrointestinal stromal tumors of the stomach.
Surg Endosc. 2013;27(5):1546-54.

15. Campos Jr E, Borim AA, Parra FG, Luz GRL; Alvarenga VSF, Gonçalves SP. Lipoma submucoso gástrico: relato de um caso. Arq ciênc saúde. 2013;20(1) 27-9.

16. Waseda $Y$, Doyama $H$, Inaki $N$, Nakanishi $H$, Yoshida N, Tsuji S, et al. Does laparoscopic and endoscopic cooperative surgery for gastric submucosal tumors preserve residual gastric motility? Results of a retrospective single-center study. PLoS One. 2014;9(6):e101337.

17. Lee $\mathrm{CM}$, Kim HH. Minimally invasive surgery for submucosal (subepithelial) tumors of the stomach. World J Gastroenterol. 2014;20(36):1303543.

18. Fletcher CD, Berman JJ, Corless C, Gorstein F, Lasota J, Longley BJ, et al. Diagnosis of gastrointestinal stromal tumors: a consensus approach. Hum Pathol. 2002;33(5):459-65.

19. Wood EH. The National Comprehensive Cancer Network (NCCN). J Med Libr Assoc. 2004;92(3):382-3.

20. Novitsky YW, Kercher KW, Sing RF, Heniford BT. Long-term outcomes of laparoscopic resection of gastric gastrointestinal stromal tumors. Ann Surg. 2006;243(6):738-45; discussion 745-7.

Recebido em: 25/10/2015

Aceito para publicação em: 18/03/2016

Conflito de interesse: nenhum.

Fonte de financiamento: nenhuma.

Endereço para correspondência:

Pedro Henrique Lambach Caron

E-mail: pedrocaron29@hotmail.com 